\title{
COMPARATIVE INVESTMENT ANALYSIS OF RECOMMENDED COCONUT HYBRIDS/CULTIVARS FOR THE NATIONAL PLANTING/REPLANTING PROGRAM IN THE PHILIPPINES
}

\author{
By \\ G. A. Santos, S. M. Rivera, R. L. Rivera \\ G. B. Baylon, B.V. dela Cruz ${ }^{1}$
}

\begin{abstract}
Comparative investment analysis was done on the eight coconut hybridsl cultivars under the Zamboanga condition using the Multiple Budget (MULBUD) program. The, study aims to ovaluate and compare the economic profitability qf coconut hybrids/cultivars under two planting schemes and determine the best genetic materials that will provide the highest economic returns to coconut farmers. Analysis of the recommended varieties was also done using different product groups and coco-based enterprises. The economic performance of each coconut hybrids1cultivars was measured using investment indicators like SNPV, BCR, and IRR.
\end{abstract}

With copra and shell as products under the new planting scheme, the use of PCA recommended local hybrids and BAY is a more profitable investment compared with MAWA and the other tall populations. In general, the profit-ability of coconut hybrids and cultivars was enhanced under the replanting scheme. Break even point was attained at year one due to the value of coconut timber obtained from the old stand.

Results further indicated that the use of local hybrids and BAY is the best starting point in increasing farm income. However, higher returns were obtained when product utilization are diversified and coco-based enter- prises are incorporated.

\section{INTRODUCTION}

In order to arrest the declining coconut production as well as maintain its leadership in coco export products and provide basic raw materials for by-products having more export values, the Philippine government embarked on a nationwide coconut planting/reolanting program in the mid-70's. The hybrid MYD x WAT (MAWA) was used in the program covering a total of 60,000 hectares in 1982. However, the large scale planting of MAWA throughout the country encountered major problems because of the location specificity of the material and its production of smaller nuts, which produced negative reactions from the farmers.

The Philippine Coconut Authority has come up with four promising selections from its trials in Zamboanga in 1989 after 15 years of genetic research on coconut (Bahala, R.T., et al, 1989). These selections were found to possess outstanding basic agronomic features which could very well satisfy the urgent need and the increasing demand for more superior types of coconut for utilization in the national planting/replanting program.

However, the farmers' active participation is crucial to the success of this program. The farmers do not not only want to know how much they can produce when these recommended materials are used but on how much they can earn from the project. Hence, this paper highlights the investment analysis of these promising materials with the inclusion of four other coconut cultivars.

\footnotetext{
${ }^{1}$ Breeding \& Genetics Division PCA-Zamboanga Research Center San Ramon, Zamboanga City.
} 
Moreover, the options available for the farmers to increase their income are never limited. It is along this line that the PCA launched a campaign on Coco-based farming systern (CBFS) and encouraged the utilization of coconut products and by-products to increase land utilization and productivity per unit area and to increase coconut production and overall farm income. Hence, two portions of this paper highlight the econornic performance of the recommended hybrids and cultivars when product utilization are diversified and when other coco-based enterprises are incorporated.

\section{OBJECTIVES}

a. Determine the econornic profitability of eight promising coconut hybrids/cultivars;

b. Evaluate and compare the econornic performance of these cultivars under two planting schemes;

c. Evaluate and compare the econornic performance of selected/ recommended hybridsand cultivar using different product-groups and using two coco-based enterprises; and

d. Determine the best material (s) that will provide the highest econornic returns to coconut farmers.

\section{MATERIALS AND METHODS}

\section{Selection and Production of Materials}

Three locally produced coconut hybrids namely, PCA 15-1 (CAT x LAG), PCA 15-2 (MRD $\mathrm{x}$ TAG), and PCA 15-3 (MRD x BAY) and four local talls namely, Baybay (BAY), San Ramon (SNR), Tagnanan (TAG) and Laguna (LAG) were selected from the pool of 42 hybrids (established in 11 genetic trials) and 98 populations/ accessions of the PCA-Zarnboanga Research Center genebank. These materials were found to be highly productive and possess econornically and socially desirable traits e.g. bigger nuts (Table 1). The foreign hybrid MAWA served as the control.

Following the standard selection of mother palms, the controlled hand pollination technique was employed in order to produce the F1 hybrid nuts while the local talls were produced by open-pollination (OP).

\section{Reld Establishment, Maintenance and Upkeep}

Field planting was done when the seedlings were about 8-10 months old. The randornized complete block design (RCBD) was used with 6-9 replicates and an elementary plot size of 15-24 palms. Distance of planting ranged from 8.5-9.0 meters. Triangular systern of planting was used.

The annual nutritional requirement of the palms is shown in Table 2. Other farm upkeep included ring weeding, field sanitation, pest/disease monitoring and control, and establishment of cover crops.

\section{Investment Analysis}

A comparative investment analysis of eight coconut cultivars under Zamboanga Research Center's condition was done using the Multiple Budgeting (MULBUD) program. Yield profile of each cultivar for 13 years was used (Table 3 ). 
Other assumptions used in the analysis are, asfollows:

a. Labor costs both for family and hired at P85.00/man-day;

b. Available family labor at $100 / \mathrm{md} / \mathrm{year}$ i.e. one family member available four hours a day to work on one-hectare coconut farm.

c. Price of copra/100kg used was the average of five (5) normal years (1988 - 1992) placed at P571.60.

d. Farm gate price for ail cultivars except MAWA of coco shells, the by-product in copra processing, was valued at P15.00/100 nut pieces; buko at P2.00/pc; and husked nuts at PI.75/pc. For MAWA, cocoshells was valued at P12.00/100np; buko at PI.50/pc; and husked nuts at $\mathrm{P} 1.25 / \mathrm{pc}$.

e. The minimum recommended cultural management practices for coconut as a monocrop were likewise assumed for ail cultivars.

f. The planting schemes used are in line with the national coconut planting/replanting program being implemented by PCA under the Small Coconut Farmers Development Project (SCFDP).

g. Logs felled in the replanting scheme were valued at P150.00/ palm on a contract basis i.e. the buyer fells and collects the palms.

h. An annual discount rate of $18 \%$ was also assumed.

\section{The Investment analysis is divided into three (3) parts.}

First, the eight coconut hybrids/cultivars were subjected to investment analysis using two planting schemes, namely, new planting and replanting. Products used are copra and shell. for the new planting scheme and copra, shell and logs for the replanting scheme.

Second, investment analysis of the recommended hybrids and cultivar was done using different product groups as follows:

New Planting Scheme:

a) Copra and shell

b) Husked nuts

c) Buko

d) Copra, shell, husked nuts, and buko

Total nut production is utilized as follows:

Husked nuts - 10\%, Buko - 10\%, Copra - $80 \%$

e) Copra, shell, toddy

Nut production is assurned to decreaseby 50\%. A total of 100 palms/ hectare is used for toddy production following the procedure of Sequential coconut toddy and nut production (SCTNP). A sharing system was used where the owner and tapper get $1 / 3$ and $2 / 3$ of the total toddy production, respectively.

\section{Replanting Scheme:}


Same groupings as in new planting scheme but with the addition of logs.

Third, analysis was done using two coco-based enterprises.

a) Coconut with intercrops

About 2,500 sq. meters are devoted to each of the intercrops. Schedule of crop introduction is as follows:

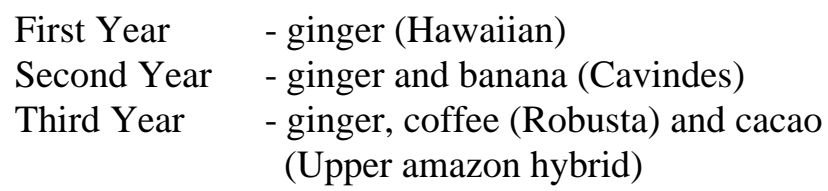

b) Coconut with cattle

A sharing system between the cattle owner and the coconut farmer is utilized so as not to burden the farmer with the initial investment. The owner shoulders the cost of the initial investment for 2 heads of cattle and the farmer takes care of the cattle with a 50\% share of the produce. Cattle is introduced on the 7 th year.

\section{Investment indicators}

The different investment indicators were computed using the MULBUD computer program.

1. Sum of the Net Present Value (SNPV) per year - SNPV per year is the cumulative discounted value of the net revenue received in each year. It was used in determining the discounted payback period or break even point.

2. Overall SNPV (@ 18\%) - This shows the net benefits of a hectare of coconut farm over the whole period of analysis at the discount rate of $18 \%$.

3. Benefit Cost Ratio (BCR) - The ratio of discounted benefit streams and the discounted cost streams.

4. Internal Rate of Return (IRR) - The discount rate that equates the SNPV to zero. It is the return of investment.

\section{RESULIS AND DISCUSSION PRODUCTION ANALYSIS}

\section{Growing Conditions at Zamboanga}

The agro-climatic condition of PCA-ZRC had been fairly normal from 1979 up to the middle of 1982 (Table 4). In 1982 and 1983, a severe drought was experienced ail over the country.

\section{Yield precoe-ity/prorile}

The yield performance and precocity of a coconut cultivar/hybrid are two major factors that determine the decision of coconut farmers in choosing a particular planting material. High yielding coconut varieties have the edge especially when the farmers can benefit from them at the earliest possible time. Among the eight coconut hybrids/cultivars evaluated, PCA 15-1, PCA 15-2 and 
MAWA started nut produefion at the age of four years from field planting. The local hybrid PCA 15-3 reached first nut harvest at the age of 5 years while the local, talls BAY, SNR, TAG and LAG started fru.it bearing on the 6th year from field planting (Table 3).

The yield potential of coconut increases with age and stabilizes when the palms are 10 years old or over (Table 5). PCA 15-1, PCA 15-2 and BAY yielded 4 to 6 tons copra per hectare in 1999 when they were 10-11. years of age from field planting. PCA 15-3, on the other hand, had a more interesting yield performance. In 1989, it produced almost 4.4 tons of copra per hectare at the age of 7 years. Among the local talls, BAY had the highest and most stable yield performance. During the 1989, 1990 and 1992 seasons, BAY yielded 4.5, 4.7, and 4.5 tons/ha., respectively.

General fluctuations in the copra yield performance were recorded between years particularly in 1984 and 1988 due to the long dry spell during the preceding year (Fig. 1 a \& lb).

\section{Basic features of the prornising materials}

The basic agronomic and chemical attributes of a coconut hybrid/cultivar are good indicators of the variety's merits for recommendation as planting material (Table 6). The coconut hybrids generally flower earlier than the local talls. Consequently, they bear fruit one to two years earlier than local cultivars. The local talls, however, has bigger nuts, than the coconut hybrids and MAWA. Hence, they needed only an average of $3.25-3.45$ nuts to produce one kilogram of copra while the local hybrids and MAWA needed an average of 4.10 - 4.33 nuts; and 5.57 nuts, respectively, to make one kilogram of copra.

The observed higher copra yield per nut of local talls (e.g. BAY) when compared to their hybrid counterpart may be attributed not only to their bigger nuts but also to the large amount of meat they produce per nut (475.70-534.0 gm). MAWA yielded only an average of 299.10 grams of meat per nut and has the lowest fruit quality value (FQV) of .37 among the eight cultivars. The three local hybrids, however, are comparable to the local talls in their nut component characters and FQV.

Two main factors generally determine copra yield per hectare, namely, the number of nuts; produced and copra yield per nut. Coconut hybrids are characterized with higher nut production but lower copra recovery per nut while the local talls produce lesser number of nuts; but have higher copra yield per nut. However, the higher nut production of the coconut hybrids more than compensate for their lower copra yield per nut.

\section{INVESTMENT ANALYSIS UNDER TWO PLANTING SCHEMES}

\section{New Planting Scheme}

The coconut hybrids started earning positively on the 4th to 5th year while the local talls recorded positive net returns on the 6th to 8th year (Table 7). PCA 15-2 was the earliest among the hybrids to record a positive net returns on the 4th year amounting to P1,284.19 while BAY started earning positively ahead of SNR, TAG and LAG on the 6th year with net returns of P4,148.44.

From year 7 onwards, the yearly net returns for the local hybrids do not fall below P5,254.47 but could go up to P23,847.50 (Table 8). Bi-yearly fluctuations were noted in all cultivars. The foreign hybrid MAWA recorded a low net returns of P5,714.30 on year 8 but posted a high net returns of P12,368.31 on year 1 1. On the other hand, from year 8 onwards, annual net returns for $\mathrm{BAY}$ and the other talls ranged frorn $\mathrm{P} 7,607.30$ to, $\mathrm{P} 23,825.53$ and $\mathrm{P} 4,326.52$ to $\mathrm{P} 18,835.14$, respectively. 
The local hybrids reached break-even point on year 10 while MAWA reached break-even point at year 1 1. Payback period for BAY is at year 12 with SNPV value of P2,386.28. SNR, TAG and LAG have not yet reached break-even point during the period of analysis. The precocity of the hybrids coupled with higher yield performance contributed to the early attainment of their discounted payback period.

Other economic indicators revealed higher profitability in using the local hybrids than the foreign hybrid MAWA and local talls. IRR for PCA 15-1 and PCA 15-2 are 31.0\% and $31.9 \%$, respectively, while MAWA and the local talls have an IRR ranging from $21.3 \%$ to $29.2 \%$.

Results suggest that the use of local hybrids under new planting scherne with copra and shell as products can be a profitable investment. In the absence of these local hybrids, however, the local tall BAY can also be used because of its high and stable yields which are comparable to the foreign hybrid MAWA in the long run.

Unlike the other hybrids and cultivars, the hybrid PCA 15-3 or MRDXBAY was only 10 years old during this period of analysis. However, its economic performance is verv prornising. This hybrid had posted positive net returns on its 5th year with a value ot P4,465.58. Break-even point was on the 10th year. BCR and IRR are 1.83 and $32.4 \%$,, respectively.

\section{Replanting Scheme}

All the coconut cultivars evaluated posted positive SNPV frorn year 1 onwards under the replanting scherne with copra, shell and logs as products (Table 9). The initial incorne from the sale of logs which amounted to P20,250.00 has greatly contribUted to the early attainment of break-even point.

All the eight coconut cultivars posted an IRR of greater than $100 \%$. However, in terms of BCR, ail the local hybrids together with local talls BAY and SNR outperformed MAWA. MAWA has a BCR value of 2.42 while PCA 15-1, PCA 15-2, BAY and SNR have BCR values of 2.67, 2.68, 2.75 , and 2.45 , respectively.

\section{Compatison of Planting Scheme}

Initial investment for new planting scherne was higher than for the replanting scheme regardless of the coconut hybrids/cultivars used (Fig. 2). This is due to the higher labor cost needed for a newly opened area.

The early advantage of replanting scherne over the new planting scherne can be accounted not only to the lower labor cost of the former at the early years of production but also to the initial income it receives from the sale of logs.

\section{INVESTMENT ANALYSIS USING DIFFERENT PRODUCT GROUPS}

\section{New Planting Scheme}

A coconut farmer whose produce is sold as copra and shell coupled with toddy production has the highest IRR among the five product groups (Table 10). IRR ranges from $55.9 \%$ to $68.4 \%$ while BCR ranges from 3.41 to 4.31 .

Likewise, the buko group performed well due to the good price it commands in the market and the lower labor and material costs required since processing is not needed. Hence, in areas where there is a high demand for this product, the production of buko is very much advisable. Using 
the recommencled local hybrids and cultivar, IRR for the buko group ranges from $32.4 \%$ to $40.6 \%$. and BCR ranges, from 2.17 to 2.62 .

Similarly, costs incurred in producing husked nuts are much lower than in producing copra. When products are sold as husked nuts, the coconut farmer gets an IRR of $36.6 \%$ to $37.8 \%$ for the local hybrids and $30.1 \%$ for the local tall BAY. BCR ranges from 1.94 to 2.30. Again, demand for husked nuts should be available for this product group to be economically feasible.

The most common practice by farmers is to plant coconut for copra production. This practice has an IRR of $28.7 \%$ to $32.4 \%$ and BCR of 1.72 to 1.83 when the recommended hybrids/cultivars were used. However, IRR and BCR can still increase when copra production is coupled with either buko and husked nuts. Under this group, IRR and BCR ranges from $29.0 \%$ to $33.4 \%$ and 1.76 to 1.91 , respectively.

The results clearly show the economic profitability of product diversification especially when the market is available and the demand is high.

\section{Replanting Scheme}

BCR and IRR for ail product groups under the replanting scherne are higher than those under the new planting scherne due to the initial income coming from the sale of logs (Table 11). Likewise, ail hybrids/cultivar under the various product groups registered an IRR of greater than $100 \%$.

\section{Comparative Advantage of Product Diversification}

Compared to the copra and shell group, an improvernent in the econornic performance of ail the hybrids/cultivar were noted when the produce is sold as husked nuts, buko, or a combination of copra, husked nuts, buko and shell. A more drarnatic increase in income was noted when toddy was introduced.

Hence, the farmers can initially increase their income even under the traditional copra and shell group when local hybrids and BAY are used. However, higher returns can be obtained when products are diversified. The farmers, therefore, have additional options if increased income is truly desired. In the process, the farmers initiative and drive to strive higher will spell the difference.

\section{INVESTMENT ANALYSIS USING TWO COCO-BASED ENTERPRISES}

A one-hectare coconut farm with planting distance and systern of $9 \times 9$ meters triangular has only a land use index (LUI) and light intensity index (LII) of $24.03 \%$ and $60.0 \%$, respectively. These figures suggest greater opportunities for the coconut farmers to optimize the use of their farm.

\section{Coconut Based Cropping Pattern}

Research results point to the success of several intercrops like cacao, coffee, banana, and several annual crops like ginger and legurnes. In this analysis, a coco land planted to either of the recom mended local hybrids and local tall BAY will serve as the base enterprise. A sketch plan is shown in Figure 3. Table 12 and 13 show the climatic and soil requirements of the intercrops used in this analysis.

Using this cropping systern, ail the recommended coconut hybrids and cultivar reached break even point on the first year (Table 14). Total net returns on year 1 ranges from P3,613.32 to 
P3,995.82. The introduction of annual crops like ginger greatly contributed to these results. BCR ranges from 2.51 to 2.54 while IRR was greater than $100 \%$.

Dramatic increases in the net income using this'eropping pattern from year one onwards were noted (Table $15 \&$ Fig. 4). The annual net returns of the recommended hybrids and cultivar using the coconut based cropping systern ranges from P3,613.32 for year 1 to as high as P60,754.47 on year 13 .

Ginger had the highest contribution to the gross income ranging from $42.3 \%$ to $47.2 \%$ (Figure 5). Banana and coconut contributed by a range of $21.0 \%$ to $22.6 \%$ and $15.7 \%$ to $20.3 \%$, respectively.

The inherent characteristics of each crop greatly affected the amount of their contribution to the gross income. However, the introduction of other crops can provide an interesting and profitable agricultural business venture for the coconut farmer. Their desire to increase their income is never limited.

\section{Coconut-Livestock Enterprise}

Cattle can also be an added enterprise considering its usefulness in reducing labor costs specifically for weed control. Normally, an average coconut farmer cannot afford to buy his own cattle for this enterprise due to the high initial investment. A common practice in Region 9 is the sharing systern where the owner allows the farmer to take care of his cattle on the condition that the first sibling will be the share of the farmer caretaker while the next sibling will be the share of the cattle owner. The next batches of siblings will follow the same arrangement. Usually, this systern Is based on trust. The farmer's main capital is his character and labor.

When cattle is introduced on the 7th year from field planting of coconut palm, the farmer will increase its annual net income from the 9th yea, onwards regardless of the cultivar used (Table 16). The annual added income from cattle ranges from $\mathrm{P} 2,212.00$ to $\mathrm{P} / 2,712.00$. IICR is 1.393 and IRR is 37.50 .

Average family labor used per year for cattle is about 22.80 man-days. Hence, the asstimed 100 mandays of family labor available per year is enough to handle a hectare of a coconut farm with cattle.

\section{CONCLUSION AND RECOMMENDATION}

With copra and shell as, products under the new planting scherne, the use of the local hybrids PCA 15-1, PCA 15-2, and PCA 15-3 as well as the local tall BAY proved to be a more profitable investment than the use ol MAWA and other local talls. The inherent precocity, higher and stahle nut production and comparable copra recovery of these cocontit hybrids/cultivar contributed to their higher profitability.

The profitability of the coconut hybrids and cultivars was enhanced under the replaming scherne. The high labor cost required in opening a new area lor coconut production contributed to the higher initial investment cost for the new planting scheme than the replanting scheme. Moreover, the initial income from the sale of logs was computed to he more than enough to cover the costs incurred during the non-pioductive years of the palms. Hence, the use of coconut hybrids under the replanting scheme is advisable for the farmers to attain brcak-even point at year one. 
Utilization of coco-products and by-products increased the economic returns from investment. Viable marketing strategies should, however, support production and utilization of the different coco-products and by-pioducts.

The production per unit area of one hectare coco-farm increased. with the use of intercrops and livestock resulting in higher returns. Annual crops like ginger contributed to the attainment of break-even point at year 1. Other perennial crops helped optimize the use of the land.

Finally, the use of PCA recommended hybrids and cultivar is the best starting point in increasing farm income. With concerted efforts to increase the utilization of the different coco-products and by-products as well as optimize the utilization of the coconut farm through the introduction of other enterprises, the coconut farmer is facing an interesting and profitable agricultural venture.

\section{ACKNOWLEDGMENT}

The PCA-ZRC Breeding and Genetics Division under the leadership of Mr. Gerardo A. Santos would like to acknowledge the following persons for their valuable contributions to this paper.

Ms. Edna Aguilar of FSSRI, UP Los Banos for her assistance in the analysis made using the MULBUD Computer program.

Dr. Severino S. Magat, Department Manager III/Scientist IV and Mr. Manuel M. de Castro of the Agricultural Research Department, PCA, DIliman. Quezon City for their valuable comments and suggestions.

PCDM Romeo Enriquez, Mr. Nelson Chua and the CDOs of PCA, Zamboanga City for their contribution in the conduct of the survey in Zarnhoanga City.

\section{REFERENCES}

GITTINGER, J. P. 1982. Economic Analysis of Agricultural Projects. Second Edition,Completely revised and expanded, Economic Development Institute of the World Bank.

MARAVILLA, J.N. and S.S. MAGAT. 1993. Sequential Coconut Toddy (sap) and Nut Production in 'laguna' tall variety and hybrid coconuts (unpublished paper).

NOTARIO, FLORECITA D. 1991. Socio-Economic Study of the Coconut Industry. In Coco-based Farming Systems - State of the knowledge and practice. Department of Agriculture/Bureau of Agricultural Research, pp. 5-28.

VILLEGAS, LINA G. 1991. Socio-Economic Study of the Coconut Industry. In Coco-based Farming Systems - State of the knowledge and practice. Department of Agriculture/Bureau of Agricultural Research, pp. 109-177.

Intercropping Coconut with banana. PCA-ARDB/PIO (Monograph, 9pp)

Intercropping Coconut with coffee. PCA-ARDB/PIO (Monograph, 14pp)

Intercropping Coconut with cacao. PCA-ARDB/PIO (Monograph, 1Opp) 
In Mulbud 16-bit version manual.

Intercropping Coconut with ginger. PCA-ARDB/PIO (Monograph, 1Opp)

Breeding and Genetics Annual Report, 1990

Breeding and Genetics Annual Report, 1991

Breeding and GeneticsAnnual Report, 1992

Philippine Recommends for Coconut, 1993

Table.1 Basic information of the parenta 1 sources of the recommended variety hybrids/cultivars

$\begin{array}{lcc}\text { MATERIAL } & \text { ORIGIN } & \text { DATE } \\ & & \text { PLANTED } \\ \text { PCA 15-1 } & \text { PHGC O3 } & \text { MAY } \\ \text { (CAT x LAG) } & & 1978\end{array}$

PCA $15-2$

(MRD x TAG)

PCA 15-3

(MRD x BAY)
PHGC O4 JANURY
1979

\section{CHARACTERISTICS OF PARENTAL POPULATIONS}

Catigan (CAT) as female parent, early bearing local green dwarf originated in Catigan, Davao City nuts are medium sized, round with protruding stigmatic tip, peduncle and spikelets are long, highly tolerant to Phyto phthora fruit and bud rot disease.

Laguna (LAG) as male/pollen parent, a late-bearing tall, produces fairly large number of medium-sized round nuts. Possesses appreciable tolerance to strong winds and Phytophthora bud rot disease.

Malayan Red Dwarf (MRD) - as female parent, an introduced dwarf variety, comes into bearing in 2-3 years. Young nuts and petiole of young leaves are bright oranye in color, produces numerous but small nuts.

Tagnanan (TAG) - as pollen source, produces nuts with good fruit composition and high copra per nut content, relatively homogenous.

Malayan Red Dwarf (MRD) same as PCA 15-2.

Bayhay (BAY) - as pollen source, possesses very firm and robust 
stem, produces medlum to large nuts with thin husk, exhibits tolerance to foliar decay disease (FDMT), which causes yellowing and eventual death of coconuts in Vanuatu.

Table 2. Fertilizer recommendation ror coconut growing

\begin{tabular}{|l|c|c|c|c|}
\hline \multirow{2}{*}{ Period } & \multicolumn{3}{|c|}{ Rate/Kind Fertilizer (grams/palm) } \\
\cline { 2 - 5 } & $\begin{array}{c}\text { Ammonium } \\
\text { Sulfate }\end{array}$ & $\begin{array}{c}\text { Potassium } \\
\text { Sulphate }\end{array}$ & Sodium & Chloride* \\
\hline Field planting & 150 & 100 & & \\
6 months & 200 & 150 & & \\
Year 1 & 500 & 500 & & \\
Year 2 & 750 & 750 & & \\
Year 3 & 1,000 & 1,000 & & \\
Year 4 & 1,500 & 1,250 & & \\
Year 5 \& up & 2,000 & 1,500 & 1,200 & \\
\hline
\end{tabular}

*Used alternately with $\mathrm{KCl}$ from year 5 and up.

Table 3. Basic information on the hybrids/cultivars under evaluation

\begin{tabular}{|l|l|c|c|c|}
\hline \multicolumn{1}{|c|}{ Hybrid/Cultivar } & Year Planted & $\begin{array}{c}\text { No of yers } \\
\text { Analyzed }\end{array}$ & $\begin{array}{c}\text { Age of 1 } \\
\text { Nut harvest }\end{array}$ & $\begin{array}{c}\text { Density } \\
\text { (Palms/ha) }\end{array}$ \\
\hline PCA 15-1 & May 1978 & 13 & 4 & 144 \\
PCA 15-2 & Jan 1979 & 13 & 4 & 144 \\
MYD x WAT & May 1978 & 13 & 4 & 144 \\
Baybay Tall & Sep 1978 & 13 & 6 & 144 \\
San Ramon Tall & Nov 1977 & 13 & 6 & 144 \\
Tagnanan & Nov 1977 & 13 & 6 & 144 \\
Laguna & Apr 1976 & 13 & 6 & 144 \\
PCA 15-3 & Mar 1982 & 10 & 5 & 144 \\
\hline
\end{tabular}


Table 4. Total rainfall (mm) by month for CY 1980-1990 and Summarized agro-climatic condition in PCA-ZRC

\begin{tabular}{|l|r|r|r|r|r|r|r|r|r|r|r|r|}
\hline $\begin{array}{c}\text { Ave } \\
\text { Month }\end{array}$ & \multicolumn{1}{|c|}{1990} & \multicolumn{1}{c|}{ A } & \multicolumn{1}{c|}{1989} & \multicolumn{1}{c|}{ A } & \multicolumn{1}{c|}{1988} & A & \multicolumn{1}{c|}{1987} & A & 1986 & A & 1985 & A \\
\hline Jan. & 5.4 & 1 & 20.2 & 5 & 14.4 & 3 & 62.6 & 7 & 61.2 & 11 & 11.9 & 4 \\
Feb. & 3.1 & 1 & 10.6 & 4 & 5.9 & 3 & 57.0 & 10 & 45.6 & 5 & 41.8 & 3 \\
Mar. & 12.4 & 3 & 6.2 & 3 & 1.8 & 1 & 32.4 & 6 & 40.6 & 9 & 54.0 & 4 \\
Apr. & 62.5 & 6 & 20.8 & 12 & 28.3 & 15 & 125.2 & 7 & 78.6 & 4 & 56.6 & 7 \\
May & 74.9 & 7 & 30.2 & 16 & 122.8 & 14 & 104.6 & 11 & 53.6 & 8 & 45.3 & 6 \\
June & 200.9 & 11 & 172.4 & 10 & 54.2 & 7 & 180.4 & 15 & 185.6 & 14 & 26.9 & 10 \\
July & 86.2 & 9 & 105.6 & 8 & 268.4 & 15 & 159.8 & 19 & 498.0 & 14 & 111.3 & 8 \\
Aug. & 55.5 & 7 & 196.2 & 19 & 289.6 & 16 & 91.1 & 10 & 83.7 & 5 & 54.2 & 9 \\
Sept. & 337.1 & 11 & 182.0 & 12 & 134.7 & 4 & 150.4 & 14 & 400.0 & 19 & 57.5 & 9 \\
Oct. & 104.1 & 10 & 190.8 & 17 & 32.8 & 5 & 87.9 & 8 & 432.9 & 21 & 315.9 & 10 \\
Nov. & 38.7 & 6 & 70.4 & 8 & 84.9 & 16 & 40.2 & 4 & 307.6 & 14 & 37.1 & 6 \\
Dec. & 14.4 & 6 & 83.9 & 9 & 120.6 & 7 & 20.1 & 4 & 7.0 & 3 & 43.0 & 5 \\
\hline Total & 995.2 & 78 & 1089.2 & 123 & 1158.4 & 106 & 1111.7 & 115 & 2194.4 & 127 & 855.5 & 81 \\
\hline
\end{tabular}

\begin{tabular}{|l|r|r|r|r|r|r|r|r|r|r|r|r|}
\hline $\begin{array}{c}\text { Ave } \\
\text { Month }\end{array}$ & \multicolumn{1}{|c|}{1984} & \multicolumn{1}{c|}{ A } & \multicolumn{1}{c|}{1983} & \multicolumn{1}{c|}{ A } & \multicolumn{1}{c|}{1982} & A & \multicolumn{1}{c|}{1981} & A & 1980 & A & $80-90$ & A \\
\hline Jan. & 150.0 & 12 & 11.0 & 2 & 69.4 & 9 & 61.9 & 9 & 58.5 & 7 & 47.86 & 6 \\
Feb. & 51.4 & 10 & 9.0 & 2 & 66.4 & 11 & 16.0 & 2 & 59.3 & 3 & 33.33 & 5 \\
Mar. & 32.4 & 6 & 44.0 & - & 10.8 & 4 & 70.3 & 6 & 3.0 & 3 & 27.99 & 4 \\
Apr. & 63,2 & 4 & 7.6 & - & 72.6 & 9 & 89.8 & 11 & 8.3 & 2 & 55.76 & 7 \\
May & 99.8 & 12 & 39.8 & - & 54.9 & 7 & 139.5 & 17 & 40.8 & 7 & 73.29 & 10 \\
June & 173.4 & 14 & 271.6 & 14 & 208.2 & 22 & 242.8 & 11 & 453.7 & 15 & 197.28 & 13 \\
July & 159.4 & 19 & 247.3 & 18 & 153.0 & 12 & 118.9 & 13 & 190.5 & 15 & 190.76 & 14 \\
Aug. & 29.2 & 6 & 166.8 & 11 & 229.2 & 11 & 71.5 & 5 & 245.6 & 12 & 137.51 & 10 \\
Sept. & 266.8 & 15 & 222.2 & 13 & 86.6 & 8 & 162.2 & 12 & 343.0 & 8 & 212.95 & 11 \\
Oct. & 485.1 & 21 & 263.6 & 14 & 336.5 & 11 & 213.2 & 15 & 493.2 & 10 & 268.73 & 13 \\
Nov. & 49.6 & 5 & 286.0 & 13 & 80.2 & 7 & 201.4 & 19 & 110.4 & 3 & 118.77 & 9 \\
Dec. & 69.0 & 5 & 142.2 & 16 & 25.1 & 8 & 67.7 & 7 & 37.3 & 9 & 57.29 & 7 \\
& & & & & & & & & & & & \\
\hline Total & 1629.3 & 129 & 1711.1 & 144 & 1393.4 & 119 & 1455.1 & 127 & 2043.6 & 94 & 1421.5 & 110 \\
\hline
\end{tabular}

(A) - number of rainy days

Summarized agro-climatic conditions: Dry months: December-May

Soil type: Silty clay loam

Annual Water Deficit : :674.1 Topographhy : Flat

Temperature (c) Minimum : 25.8 Landfrom : Coastal

Maximum : 30.6 
Table 5. Yield performance of four coconut hybrids and four local cultivars

\begin{tabular}{|c|c|c|c|c|c|c|c|c|c|c|c|c|c|c|c|c|}
\hline \multirow[b]{2}{*}{ Year } & \multicolumn{2}{|c|}{ PCA 15-1 } & \multicolumn{2}{|c|}{ PCA 15-2 } & \multicolumn{2}{|c|}{ PCA 15-3 } & \multicolumn{2}{|c|}{ MYD x WAT } & \multicolumn{2}{|c|}{ BAYBAY } & \multicolumn{2}{|c|}{ SAN RAMON } & \multicolumn{2}{|c|}{ TAGNANAN } & \multicolumn{2}{|c|}{ LAGUNA } \\
\hline & $\begin{array}{l}\text { Nha } \\
\text { (no) }\end{array}$ & $\begin{array}{l}\text { Cha } \\
\text { (ton) }\end{array}$ & $\begin{array}{l}\text { Nha } \\
\text { (no) }\end{array}$ & $\begin{array}{l}\text { Cha } \\
\text { (ton) }\end{array}$ & $\begin{array}{l}\text { Nha } \\
\text { (no) }\end{array}$ & $\begin{array}{l}\text { Cha } \\
\text { (ton) }\end{array}$ & $\begin{array}{l}\text { Nha } \\
\text { (no) }\end{array}$ & $\begin{array}{l}\text { Cha } \\
\text { (ton) }\end{array}$ & $\begin{array}{l}\text { Nha } \\
\text { (no) }\end{array}$ & $\begin{array}{l}\text { Cha } \\
\text { (ton) }\end{array}$ & $\begin{array}{l}\text { Nha } \\
\text { (no) }\end{array}$ & $\begin{array}{l}\text { Cha } \\
\text { (ton) }\end{array}$ & $\begin{array}{l}\text { Nha } \\
\text { (no) }\end{array}$ & $\begin{array}{l}\text { Cha } \\
\text { (ton) }\end{array}$ & $\begin{array}{l}\text { Nha } \\
\text { (no) }\end{array}$ & $\begin{array}{l}\text { Cha } \\
\text { (ton) }\end{array}$ \\
\hline 1982 & 1,258 & 0.30 & - & - & - & - & 2,214 & 0.14 & - & - & 19 & - & - & - & - & . \\
\hline 1983 & 5,211 & 1.11 & 2,970 & 0.72 & - & - & 7,709 & 1.23 & 5,670 & 1.35 & 1,634 & 0.29 & 689 & 0.18 & 1,485 & 0.23 \\
\hline 1984 & 3,159 & 0.84 & 1,890 & 0.61 & - & - & 5,265 & 1.05 & 2,295 & 0.72 & 1,539 & 0.53 & 864 & 0.32 & 270 & 0.07 \\
\hline 1985 & 10,712 & 2.73 & 10,935 & 2.69 & - & - & 13,508 & 2.65 & 10,800 & 3.24 & 5,265 & 1.72 & 4,185 & 1.36 & 8,910 & 2.27 \\
\hline 1986 & 8,505 & 2.08 & 5,130 & 1.42 & - & - & 8,910 & 1.72 & 5,805 & 1.80 & 4,320 & 1.39 & 3,510 & 1.16 & 6,075 & 1.69 \\
\hline 1987 & 9,855 & 2.39 & 8,505 & 2.00 & 7,752 & 1.36 & 11,205 & 2.12 & 10,935 & 3.21 & 6,615 & 1.89 & 4,860 & 1.28 & 7,020 & 1.77 \\
\hline 1988 & 8,640 & 1.99 & 1,755 & 0.42 & 1,368 & 0.31 & 10,260 & 1.89 & 8,505 & 2.34 & 5,400 & 1.67 & 4,455 & 1.34 & 4,185 & 1.08 \\
\hline 1989 & 14,175 & 4.06 & 17,145 & 5.18 & 15,048 & 4.39 & 14,310 & 3.06 & 14,715 & 4.52 & 11,745 & 4.09 & 9,450 & 3.43 & 5,400 & 1.51 \\
\hline 1990 & 14,580 & 3.66 & 12,015 & 3.25 & 10,944 & 2.69 & 15,660 & 2.98 & 15,390 & 4.74 & 11,475 & 3.62 & 11,205 & 3.66 & 12,150 & 3.50 \\
\hline 1991 & 12,838 & 3.34 & 12,000 & 3.00 & 9,948 & 2.43 & 14,270 & 2.56 & 10,233 & 2.86 & 10,004 & 3.19 & 7,583 & 2.38 & 7,352 & 1.73 \\
\hline 1992 & 13,117 & 2.97 & 9,746 & 2.15 & 10,423 & 2.28 & 13,348 & 2.41 & 16,200 & 4.54 & 9,059 & 2.60 & 9,664 & 2.90 & 16,605 & 4.06 \\
\hline Tota & 102,050 & 25.45 & 82,091 & 21.43 & 55,483 & 13.46 & 116,659 & 22.06 & 100,548 & 29.31 & 67,075 & 20.98 & 56,465 & 18.02 & 69,452 & 17.91 \\
\hline Mean & 9,277 & 2.31 & 8,209 & 2.14 & $9,247.17$ & 2.24 & 10,605 & 2.01 & 10,055 & 2.93 & 6,098 & 2.10 & 5,647 & 1.80 & 6,945 & 1.79 \\
\hline
\end{tabular}

NHa - Nut per hectare

Cha - Copra per Hectare 
Table 6. Basic feature of recommended variety hybrids/cultivars based on 1990 - 1992 data

\begin{tabular}{|c|c|c|c|c|c|c|c|c|}
\hline FEATURE & PCA 15-1 & PCA 15-2 & PCA 15-3 & MAWA & BAY & SNR & TAG & LAG \\
\hline \multicolumn{9}{|l|}{ Paterns } \\
\hline Female & CATIGAN & MRD & M R D & MYD & BAY AG2 & SNR & TAG & LAG \\
\hline Male & LAGUNA & TAGNANAN & BAYBAY & WAT & $(\mathrm{OP})$ & $(\mathrm{OP})$ & (OP) & (OP) \\
\hline \multicolumn{9}{|l|}{ Age (years) } \\
\hline First flowering & 3-4 & 3-4 & $3-4$ & $3-4$ & $3.5-4.5$ & $3.5-4.5$ & $3.5-4.5$ & $3.5-4.5$ \\
\hline First nut harverting & 4 & 4 & 5 & 4 & 6 & 6 & 6 & 6 \\
\hline Nut Color & $\mathrm{G} / \mathrm{B}$ & BROWN & BROWN & $\mathrm{G} / \mathrm{B}$ & $\mathrm{G} / \mathrm{B}$ & $\mathrm{G} / \mathrm{B}$ & $\mathrm{G} / \mathrm{B}$ & $\mathrm{G} / \mathrm{B}$ \\
\hline Nut Size & MEDIUM & MEDIUM & MEDIUM & SMALL & $M-L$ & $M-L$ & $M-L$ & $M-L$ \\
\hline Nut/kg of Copra & 4.18 & 4.10 & 4.33 & 5.57 & 3.45 & 3.35 & 3.25 & 4.11 \\
\hline Bunch/year & 11 & 9 & 8 & 11 & 13 & 10 & 10 & 10 \\
\hline Nuts/bunch & 9 & 9 & 11 & 9 & 11 & 9 & 8 & 8 \\
\hline Nuts/palm & 100 & 83 & 69 & 106 & 103 & 79 & 70 & 89 \\
\hline Nuts/ha/yr & 13,511 & 11,253 & 10,438 & 14,426 & 13,941 & 10,179 & 9,484 & 12,035 \\
\hline Copra/nut (g) & 239.44 & 244.82 & 230.94 & 179.42 & 289.27 & 298.24 & 307.62 & 243.33 \\
\hline Copra/palm (kg) & 23.92 & 20.32 & 15.93 & 19.01 & 29.79 & 23.56 & 21.39 & 21.66 \\
\hline Copra/ha/yr (ton) & 3.23 & 2.74 & 2.25 & 2.57 & 4.02 & 3.02 & 2.89 & 3.09 \\
\hline Wt of whole nut $(\mathrm{kg})$ & $1,294.70$ & $1,283.60$ & $1,138.80$ & 971.90 & $1,433.40$ & $1,624.60$ & $1,650.50$ & $1,222.60$ \\
\hline Wt of husk (g) & 390.20 & 320.80 & 315.40 & 363.70 & 373.20 & 421.40 & 411.70 & 339.10 \\
\hline Wt of shell $(\mathrm{g})$ & 207.10 & 209.60 & 174.20 & 145.60 & 235.50 & 262.40 & 266.70 & 196.60 \\
\hline Wt of meat $(\mathrm{g})$ & 412.90 & 443.10 & 402.80 & 299.10 & 475.70 & 518.40 & 534.00 & 412.60 \\
\hline Wt of water (g) & 284.50 & 310.10 & 246.40 & 163.50 & 349.00 & 422.40 & 438.10 & 274.20 \\
\hline Fruit Quality Value (FQV) & 0.41 & 0.46 & 0.45 & 0.37 & 0.44 & 0.43 & 0.44 & 0.43 \\
\hline Oil content (\%) & 64.30 & 62.90 & & 62.20 & 63.50 & 63.50 & 63.50 & 63.50 \\
\hline
\end{tabular}

Note: FQY = meat/whole nut - water 
Table 7. Economic performance of eight coconut hybrids/cultivars under new planting scheme with copra and shell as products

\begin{tabular}{|c|c|c|c|c|c|c|c|c|}
\hline \multirow{2}{*}{ PARICULARS } & \multicolumn{8}{|c|}{ HYBRIDS/CULTIVAR } \\
\hline & PCA 15-1 & PCA 15-2 & PCA $15-3^{\star}$ & MAWA & BAY & SNR & TAG & LAG \\
\hline Start of positive net returns/yr & 5 & 4 & 5 & 5 & 6 & 7 & 8 & 8 \\
\hline Amount & $3,800.38$ & $1,284.19$ & $4,465.58$ & $4,043.90$ & $4,148.44$ & 720.76 & $4,326.51$ & $8,911.57$ \\
\hline Break-even pt/yr & 10 & 10 & 10 & 11 & 12 & \multicolumn{3}{|c|}{ Have not reacted breack-even point } \\
\hline SNPV & 314.91 & 2366.16 & 790.74 & 1097.18 & 2386.28 & & & \\
\hline $\mathrm{BCR}$ & 1.75 & 1.76 & 1.83 & 1.57 & 1.72 & 1.36 & 1.23 & 1.23 \\
\hline IRR \% & 31 & 31.9 & 32.4 & 29.2 & 28.7 & 23.2 & 21.3 & 21.5 \\
\hline Overall SNPV (18 \%) & $17,230.26$ & $17,505.38$ & $16,982.65$ & $13,843.25$ & $15,011.79$ & $7,023.04$ & $4,388.15$ & $4,494.25$ \\
\hline
\end{tabular}


Table 8. Annual Net Returns (Year 4-13) of eight hybrids/cultivars under the new planting scheme with copra and shell as products

\begin{tabular}{|c|c|c|c|c|c|c|c|c|}
\hline \multirow{2}{*}{ YEAR } & \multicolumn{8}{|c|}{ HYBRID/CULTIVAR } \\
\hline & PCA 15-1 & PCA 15-2 & PCA 15-3 & MAWA & BAY & SNR & TAG & LAG \\
\hline 4 & $(928.65)$ & $1,284.20$ & $(2,395.00)$ & $(507.63)$ & $(2,295.00)$ & $(2,295.00)$ & $(2,295.00)$ & $(2,295.00)$ \\
\hline 5 & $3,800.38$ & $1,034.94$ & $4,465.59$ & $4,043.91$ & $(2,975.24)$ & $(3,060.10)$ & $(2,975.24)$ & $(2,975.24)$ \\
\hline 6 & 853.05 & $10,585.77$ & $2,028.25$ & $1,608.20$ & $4,148.44$ & $(1,520.53)$ & $(2,186.66)$ & $(1,878.69)$ \\
\hline 7 & $12,058.18$ & $5,254.47$ & $17,665.15$ & $10,711.10$ & $1,709.65$ & 720.76 & $(382.22)$ & $(1,697.26)$ \\
\hline 8 & $8,232.31$ & $7,893.92$ & $9,734.84$ & $5,714.30$ & $14,239.46$ & $6,183.71$ & $4,326.52$ & 8911.83 \\
\hline 9 & $10,292.05$ & 24.49 & $8,995.63$ & $8,101.08$ & $7,607.30$ & $5,479.89$ & $4,283.27$ & 6840.42 \\
\hline 10 & $7,862.57$ & $23,847.50$ & $8,601.09$ & $6,622.19$ & $14,430.53$ & $7,499.36$ & $4,330.99$ & 6624.95 \\
\hline 11 & $18,499.56$ & $14,555.85$ & & $12,368.31$ & $9,920.88$ & $6,323.76$ & $4,640.36$ & 3071.80 \\
\hline 12 & $16,074.33$ & $12,745.90$ & & $1,555.07$ & $21,265.10$ & $18,835.14$ & $15,427.75$ & $5,184.20$ \\
\hline 13 & $15,988.96$ & $10,134.09$ & & $11,227.28$ & $23,825.53$ & $17,992.63$ & $19,253.97$ & $16,798.89$ \\
\hline
\end{tabular}

Table 9. Economic performance of eight coconut hybrids/cultivars under replanting scheme with copra, shell and logs as products

\begin{tabular}{|c|c|c|c|c|c|c|c|c|}
\hline \multirow{2}{*}{ PARTICULARS } & \multicolumn{8}{|c|}{ HYBRID/CULTIVAR } \\
\hline & PCA 15-1 & PCA 15-2 & PCA 15-3 & MAWA & BAY & SNR & TAG & LAG \\
\hline Break even point & \multicolumn{8}{|c|}{ Positive SNPV from Year one (1) onwards } \\
\hline BCR & 2.67 & 2.68 & 2.88 & 2.42 & 2.75 & 2.45 & 2.34 & 2.30 \\
\hline IRR & $>100 \%$ & $>100 \%$ & $>100 \%$ & $>100 \%$ & $>100 \%$ & $>100 \%$ & $>100 \%$ & $>100 \%$ \\
\hline Overall SNPV (18\%) & $35,916.70$ & $36,191.82$ & $35,669.09$ & $32,529.69$ & $33,698.23$ & $25,709.49$ & $23,074.59$ & $23,180.69$ \\
\hline
\end{tabular}


Table 10. Internal rate of return (IRR) and benefit cost ratio of recommended coconut hybrids and cultivar using different product groups under the new planting scheme

\begin{tabular}{|c|c|c|c|c|c|c|c|c|}
\hline \multirow{2}{*}{ PRODUCT GROUP } & \multicolumn{4}{|c|}{ INTERNAL RATE OF RETURN } & \multicolumn{4}{|c|}{ BENEFIT COST RATIO } \\
\hline & PCA 15-1 & PCA $15-2$ & PCA $15-3$ & BAY & PCA 15-1 & PCA $15-2$ & PCA $15-3$ & BAY \\
\hline Copra, \& shell (A) & $31.0 \%$ & $31.9 \%$ & $32.4 \%$ & $28.7 \%$ & 1.75 & 1.76 & 1.83 & 1.72 \\
\hline Husked nuts (B) & $36.6 \%$ & $36.8 \%$ & $37.8 \%$ & $30.1 \%$ & 2.30 & 2.24 & 2.33 & 1.94 \\
\hline Buko (C) & $39.8 \%$ & $40.3 \%$ & $40.6 \%$ & $32.4 \%$ & 2.62 & 2.55 & 2.58 & 2.17 \\
\hline$A+B+C$ & $32.1 \%$ & $32.9 \%$ & $33.4 \%$ & $29.0 \%$ & 1.83 & 1.84 & 1.91 & 1.76 \\
\hline A + Toddy & $68.4 \%$ & $55.9 \%$ & $67.9 \%$ & $56.9 \%$ & 4.29 & 3.41 & 3.68 & 4.31 \\
\hline
\end{tabular}

Table I 1. Internal rate of return (IRR) and benefit cost ratio of recommended coconut hybrids and cultivar using different product groups under the replanting scheme

\begin{tabular}{|l|c|c|c|c|c|c|c|c|}
\hline \multirow{2}{*}{\multicolumn{1}{c|}{$\begin{array}{c}\text { PRODUCT } \\
\text { GROUP }\end{array}$}} & \multicolumn{3}{c|}{ INTERNAL RATE OF RETURN } & \multicolumn{4}{c|}{ BENEFFr COST RATIO } \\
\cline { 2 - 9 } & PCA 15-1 & PCA 15-2 & PCA 15-3 & BAY & PCA 15-1 & PCA 15-2 & PCA 15-3 & BAY \\
\hline Logs. copra. \& shell (A) & $>100 \%$ & $>100 \%$ & $>100 \%$ & $>100 \%$ & 2.67 & 2.68 & 2.88 & 2.75 \\
Logs \& husked nuts (B) & $>100 \%$ & $>100 \%$ & $>100 \%$ & $>100 \%$ & 3.47 & 3.42 & 3.63 & 3.16 \\
Logs \& buko (C) & $>100 \%$ & $>100 \%$ & $>100 \%$ & $>100 \%$ & 3.86 & 3.76 & 3.94 & 3.45 \\
A+ B + C & $>100 \%$ & $>100 \%$ & $>100 \%$ & $>100 \%$ & 2.78 & 2.79 & 2.98 & 2.81 \\
A + Todd) & $>100 \%$ & $>100 \%$ & $>100 \%$ & $>100 \%$ & 5.19 & 4.27 & 4.66 & 5.40 \\
\hline
\end{tabular}


Table 12. Climatic requirements of Coconut \& selected intercrops for high yield

\begin{tabular}{|c|c|c|c|c|c|c|c|}
\hline CROPS & LATITUDE & ALTITUDE & TEMP $\left({ }^{\mathrm{O}} \mathrm{C}\right)$ & $\mathrm{RH}(\%)$ & $\begin{array}{c}\text { LIGHT } \\
\text { FREQUENCY } \\
(\mathrm{ft}-\mathrm{cdl})\end{array}$ & $\begin{array}{l}\text { RAINFALL } \\
(\mathrm{mm})(\%)\end{array}$ & $\begin{array}{l}\text { TYPHOON } \\
\text { INTENSITY }\end{array}$ \\
\hline \multirow[t]{2}{*}{ Coconut } & $30^{\mathrm{O}} \mathrm{N} 20^{\mathrm{O}} \mathrm{S}$ & $<600$ & $24-29$ & $80-90$ & $>2000$ & $1500-2300$ & $<20$ \\
\hline & $\begin{array}{l}\text { Tropics } \\
\text { Subtropics }\end{array}$ & - & - & - & Sunshine hrs. & $\begin{array}{c}\text { evenly } \\
\text { distributed }\end{array}$ & - \\
\hline \multicolumn{8}{|l|}{ Intercrops: } \\
\hline \multirow[t]{2}{*}{ Banana } & Tropics & $<750$ & & $15-35$ & $3000-8000$ & $>1000$ & $<10$ \\
\hline & & & & & & $(10-12 \mathrm{mo})$ & \\
\hline \multirow{4}{*}{$\begin{array}{l}\text { Coffee } \\
\text { Subtropics } \\
\text { Cacao }\end{array}$} & Tropics & $<1000$ & $15-29$ & $70-85$ & $1000-3000$ & $1900-2500$ & $<20$ \\
\hline & & - & & & & & \\
\hline & Tropics & $<1000$ & $21-35$ & - & $1000-3000$ & $1500-2000$ & $<10$ \\
\hline & Subtropics & - & - & & & & \\
\hline
\end{tabular}

* Phil. recommends for coconut, 1993 
Table 13. Soil requirements of coconut and intercrops for high yield

\begin{tabular}{|l|c|l|c|l|l|}
\hline \multicolumn{1}{|c|}{ CROP } & $\begin{array}{c}\text { SOIL DEPTH } \\
(\mathrm{cm})\end{array}$ & \multicolumn{1}{|c|}{ DRAINAGE } & SOIL $\mathrm{pH}$ & \multicolumn{1}{c|}{ SOIL TYPE } & \multicolumn{1}{c|}{$\begin{array}{c}\text { MAJOR MACRO } \\
\text { NUTRIENTS ** }\end{array}$} \\
\hline Coconut & $>75$ & moderate to well drained & $6.0-7.5$ & sandy/loamy/clayey & $\mathrm{N}, \mathrm{K}, \mathrm{Cl}, \mathrm{S}, \mathrm{P}$ \\
Intercrops: & $>75$ & well-drained & $6.0-7.5$ & loarny/clavey & $\mathrm{N}, \mathrm{P}, \mathrm{K}, \mathrm{Ca}$ \\
Banana & $>75$ & well-drained & $4.5-6.5$ & loamy/clavey & $\mathrm{N}, \mathrm{P}, \mathrm{K}, \mathrm{Ca}, \mathrm{S}$ \\
Coffee & $>75$ & well-drained & $5.5-7.0$ & loamy/clavey & $\mathrm{N}, \mathrm{P}, \mathrm{K}, \mathrm{Ca}, \mathrm{S}$ \\
Cacao & & & & \\
\hline
\end{tabular}

** $\mathrm{Zn}, \mathrm{Fe}, \mathrm{Mn}, \mathrm{B}, \mathrm{Cu}$ must be adequate

Table 14. Economic performance of eight coconut hybrids/cultivars under the new planting scheme using a coco-based cropping pattern.

\begin{tabular}{|c|c|c|c|c|}
\hline \multirow{2}{*}{ PARTICULARS } & \multicolumn{4}{|c|}{ HYBRID/CULTIVAR } \\
\hline & PCA $15-1$ & PCA $15-2$ & PCA $15-3$ & BAY \\
\hline Start of positive net returns Year & 1 & 1 & 1 & 1 \\
\hline Amount & $3,613.32$ & $3,13.32$ & $3,613.32$ & $3,995.82$ \\
\hline Break-even point & \multicolumn{4}{|c|}{ Positive SNPV from year one (1) on wards } \\
\hline $\mathrm{BCR}$ & 2.52 & 2.52 & 2.51 & 2.54 \\
\hline IRR & $>100$ & $>100$ & $>100$ & $>100$ \\
\hline
\end{tabular}


Table 15. Annual Net Returns of recommended coconut hybrids \& cultivar using a coco-based cropping pattern, under the new planting scheme

\begin{tabular}{|c|c|c|c|c|c|c|c|c|}
\hline \multirow{3}{*}{ YEAR } & \multicolumn{8}{|c|}{ H Y B R ID } \\
\hline & \multicolumn{2}{|c|}{ PCA $15-1$} & \multicolumn{2}{|c|}{ PCA 15 - 2} & \multicolumn{2}{|c|}{ PCA $15-3$} & \multicolumn{2}{|c|}{ BAYBAY } \\
\hline & A & B & A & B & A & B & A & B \\
\hline 1 & $(8,809.18)$ & $3,613.32$ & $(8,809.18)$ & $36,13.322$ & $(8,809.18)$ & $3,613.32$ & $(8,426.68)$ & $3,995.82$ \\
\hline 2 & $(2,005.00)$ & $18,117.50$ & $(2,005.00)$ & $18,117.50$ & $(2,005.00)$ & $18,117.50$ & $(2,005.00)$ & $18,117.50$ \\
\hline 3 & $(3,411.00)$ & $15,952.65$ & $(3,411.00)$ & $15,952.65$ & $(3,411.00)$ & $15,952.65$ & $(2,311.00)$ & $17,052.65$ \\
\hline 4 & (928.64) & $21,907.07$ & $1,284.19$ & $24,119.93$ & $(2,395.00)$ & $20,440.70$ & $(2,295.00)$ & $20,540.70$ \\
\hline 5 & $3,800.38$ & $31,630.47$ & $1,034.93$ & $28,865.01$ & $4,465.58$ & $32,295.68$ & $(2,975.24)$ & $24,854.86$ \\
\hline 6 & 853.04 & $28,741.95$ & $10,585.76$ & $38,474.65$ & $(2,028.25)$ & $25,860.67$ & $4,148.4-4$ & $32,037.34$ \\
\hline 7 & $12,058.17$ & $45,144.60$ & $5,254.46$ & $38,340.90$ & $17,665.14$ & $50,751.61$ & $1,709.64$ & $34,796.07$ \\
\hline 8 & $8,232.30$ & $41,318.73$ & $7,893.91$ & $40,980.30$ & $9,734.83$ & $42,821.23$ & $14,239.45$ & $473,215.89$ \\
\hline 9 & $10,292.03$ & $44,500.98$ & 24.47 & $34,233.40$ & $8,995.61$ & $43,204.58$ & $7,607.29$ & $41,816.20$ \\
\hline 10 & $7,862.57$ & $43,321.50$ & $23,847.48$ & $59,306.43$ & $8,601.09$ & $44,060.03$ & $14,430.52$ & $49,889.46$ \\
\hline 11 & $18,499.55$ & $51,658.44$ & $14,555.84$ & $47,714.74$ & & & $9,920.86$ & $43,079.73$ \\
\hline 12 & $16,074.32$ & $51,533.21$ & $12,745.90$ & $48,204.80$ & & & $21,265.09$ & $56,723.99$ \\
\hline 13 & $15,988.95$ & $52,817.90$ & $10,134.09$ & $46,963.00$ & & & $23,825.53$ & $60,754.47$ \\
\hline
\end{tabular}

A - monocrop (coconut)

B - coconut with interops 
Table 16. Annual Net Returns (Year 4-13) of recommended coconut hybrids \& cultivar using coco-based livestock enterprise under the new planting scheme

\begin{tabular}{|c|c|c|c|c|c|c|c|c|}
\hline \multirow{3}{*}{ YEAR } & \multicolumn{8}{|c|}{ E N T E R P R 1 S E } \\
\hline & \multicolumn{2}{|c|}{ PCA $15-1$} & \multicolumn{2}{|c|}{ PCA $15-2$} & \multicolumn{2}{|c|}{ PCA $15-3$} & \multicolumn{2}{|c|}{ BAYBAY } \\
\hline & \multicolumn{2}{|c|}{ MONOCROP + LIVESTOCK } & \multicolumn{2}{|c|}{ MONOCROP + LIVESTOCK } & \multicolumn{2}{|c|}{ MONOCROP + LIVESTOCK } & \multicolumn{2}{|c|}{ MONOCROP + LIVESTOCK } \\
\hline 4 & $(2,395.00)$ & $(2,395.00)$ & $1,284.20$ & $1,284.20$ & $(2,395.00)$ & $(2,395.00)$ & $(2,295.00)$ & $(2,295.00)$ \\
\hline 5 & $3,800.38)$ & $3,800.38$ & $1,034.94$ & $1,034.94$ & $4,465.59$ & $4,465.59$ & $(2,975.24)$ & $(2,975.24)$ \\
\hline 6 & 853.05 & 853.05 & $10,585.77$ & $10,585.77$ & $2,028.25$ & $2,028.25$ & $4,148.44$ & $4,148.44$ \\
\hline 7 & $12,058.18$ & $8,982.68$ & $5,254.47$ & $2,178.97$ & $17,665.15$ & $14,589.65$ & $1,709.65$ & $1,365.85$ \\
\hline 8 & $8,232.31$ & $5,656.81$ & $7,893.92$ & $5,318.42$ & $9,723.84$ & $7,148.34$ & $14,239.46$ & $11,663.96$ \\
\hline 9 & $10,292.05$ & $12,716.55$ & 24.49 & $2,448.99$ & $8,995.63$ & $11,420.13$ & $7,607.30$ & $10,031.80$ \\
\hline 10 & $7,862.57$ & $10,787.07$ & $23,847.50$ & $26,772.00$ & $8,601.09$ & $11,525.59$ & $14,430.53$ & $17,355.03$ \\
\hline 11 & $18,499.56$ & $20,924.06$ & $14,555.85$ & $16,980.35$ & & & $9,920.88$ & $12,345.38$ \\
\hline 12 & $16,074.33$ & $18,998.83$ & $12,745.90$ & $15,670.40$ & & & $21,265.10$ & $24,189.60$ \\
\hline 13 & $15,988.96$ & $18,413.46$ & $10,134.09$ & $12,558.59$ & & & $23,825.53$ & $26,250.03$ \\
\hline
\end{tabular}



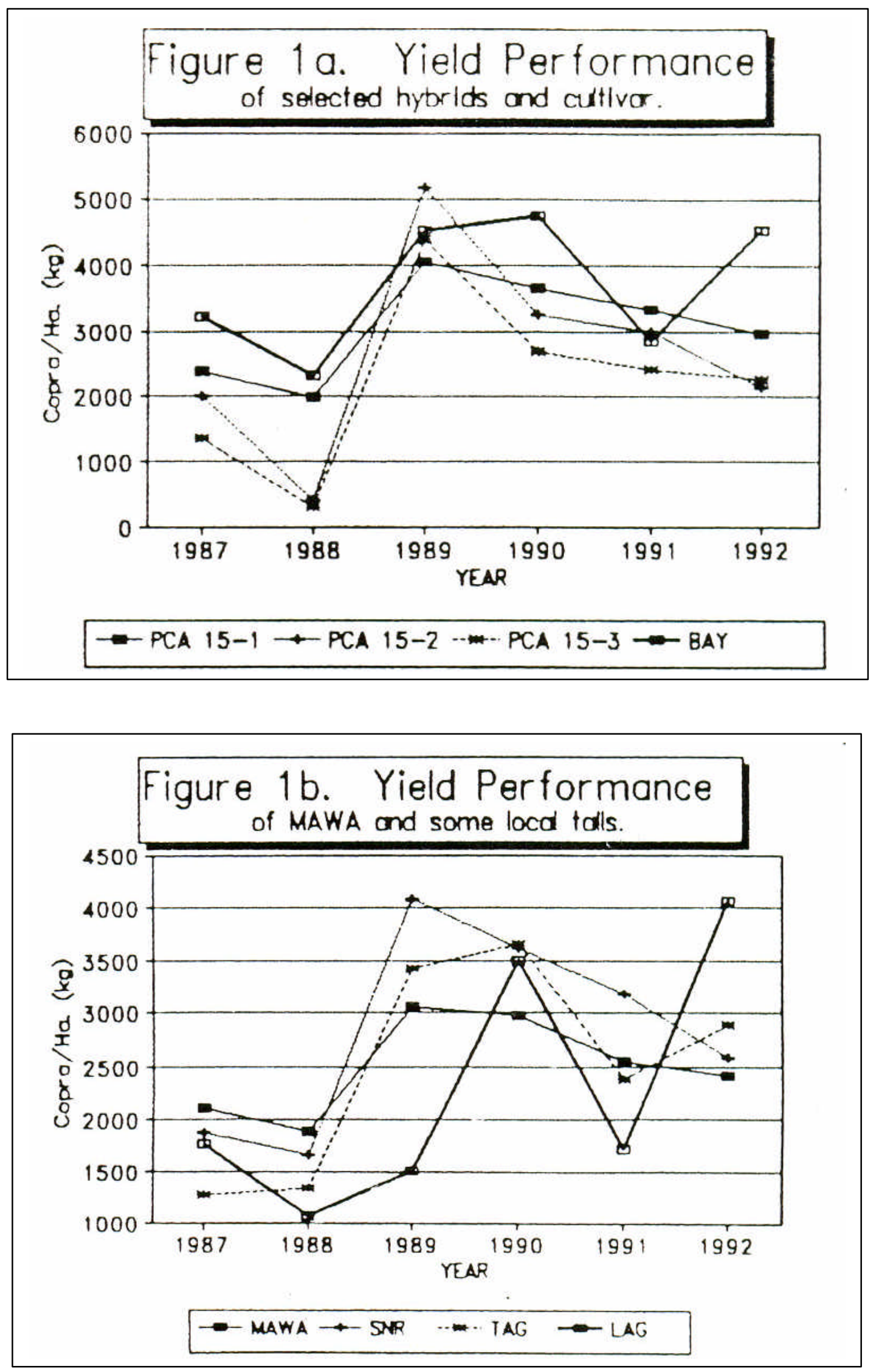


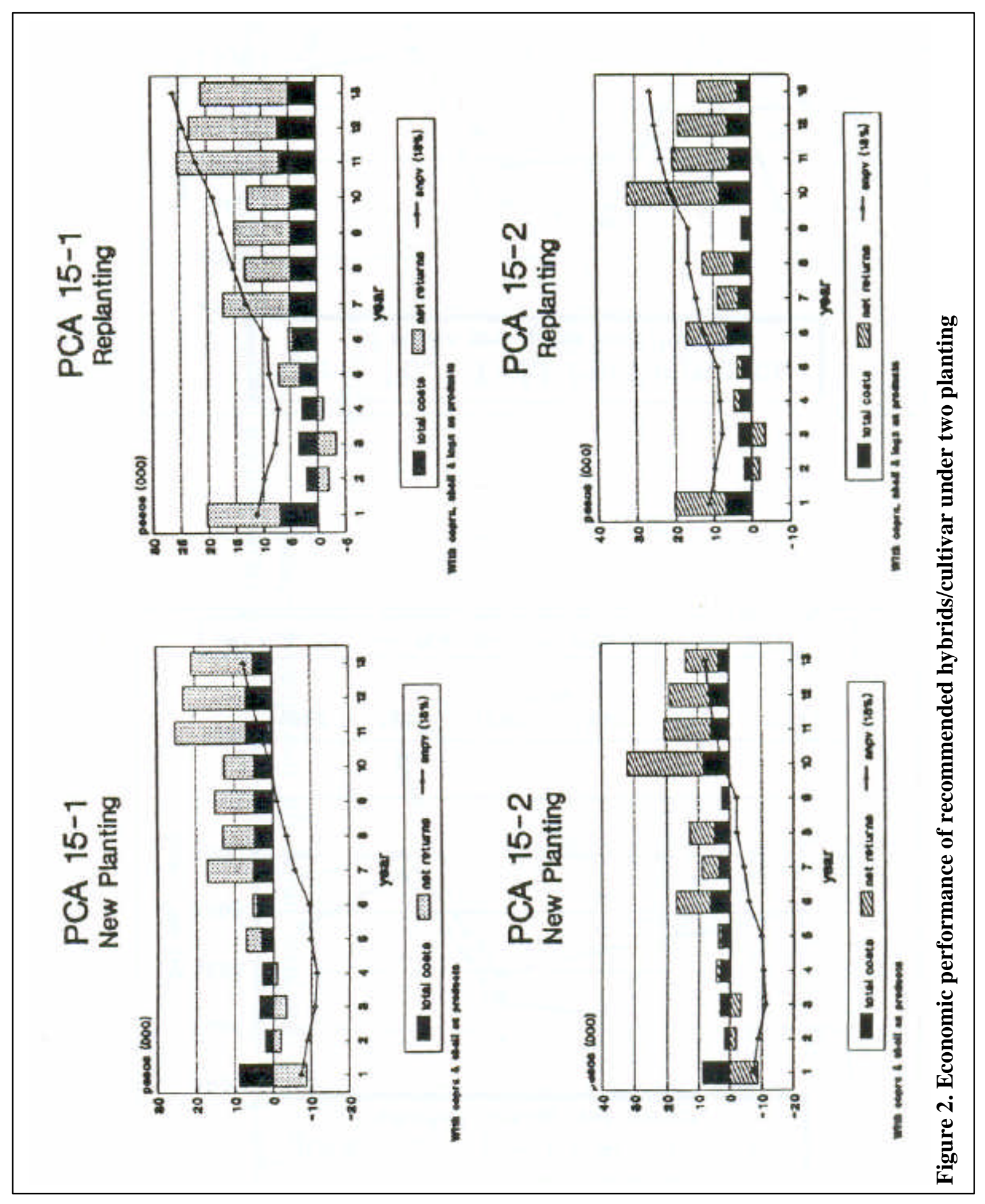




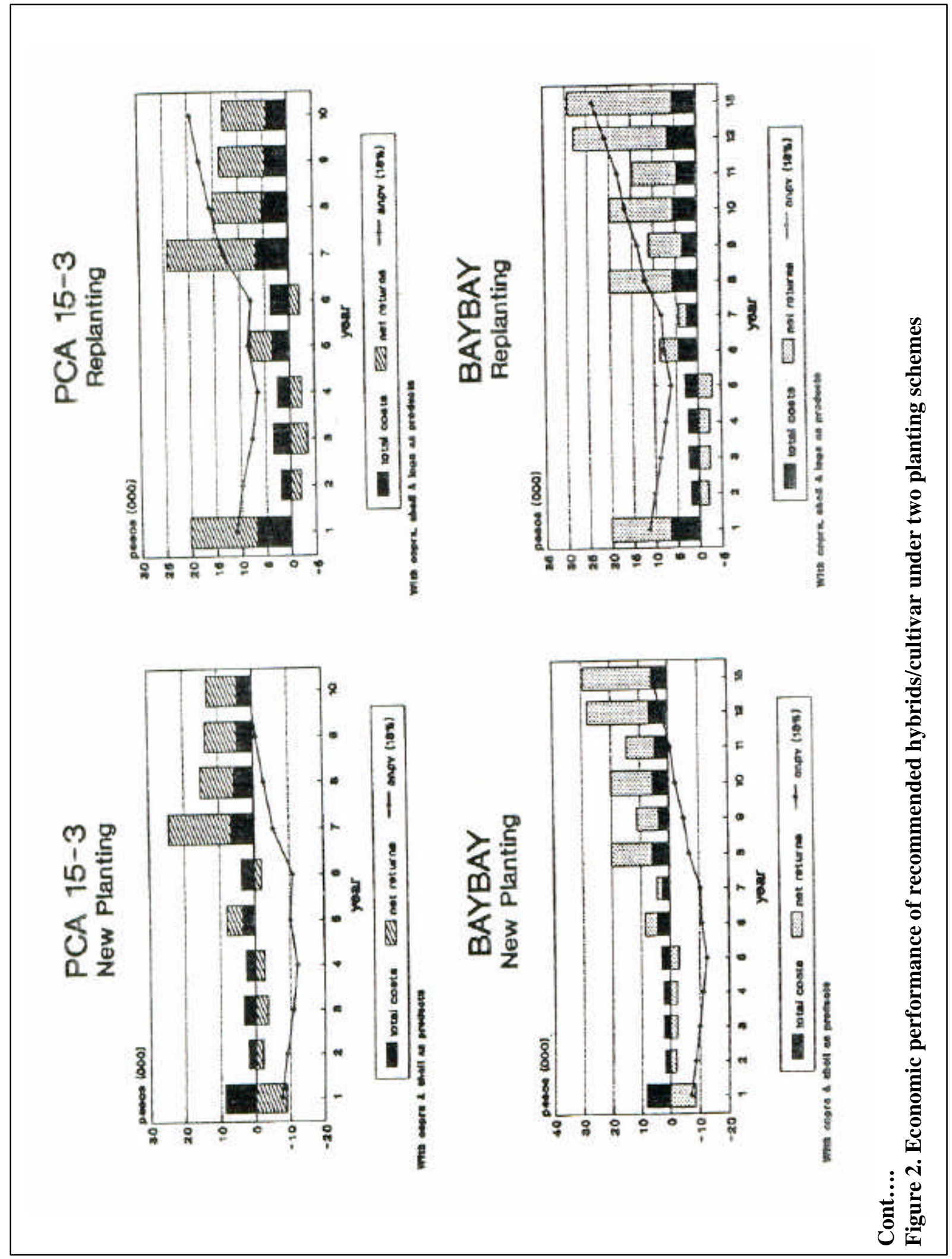




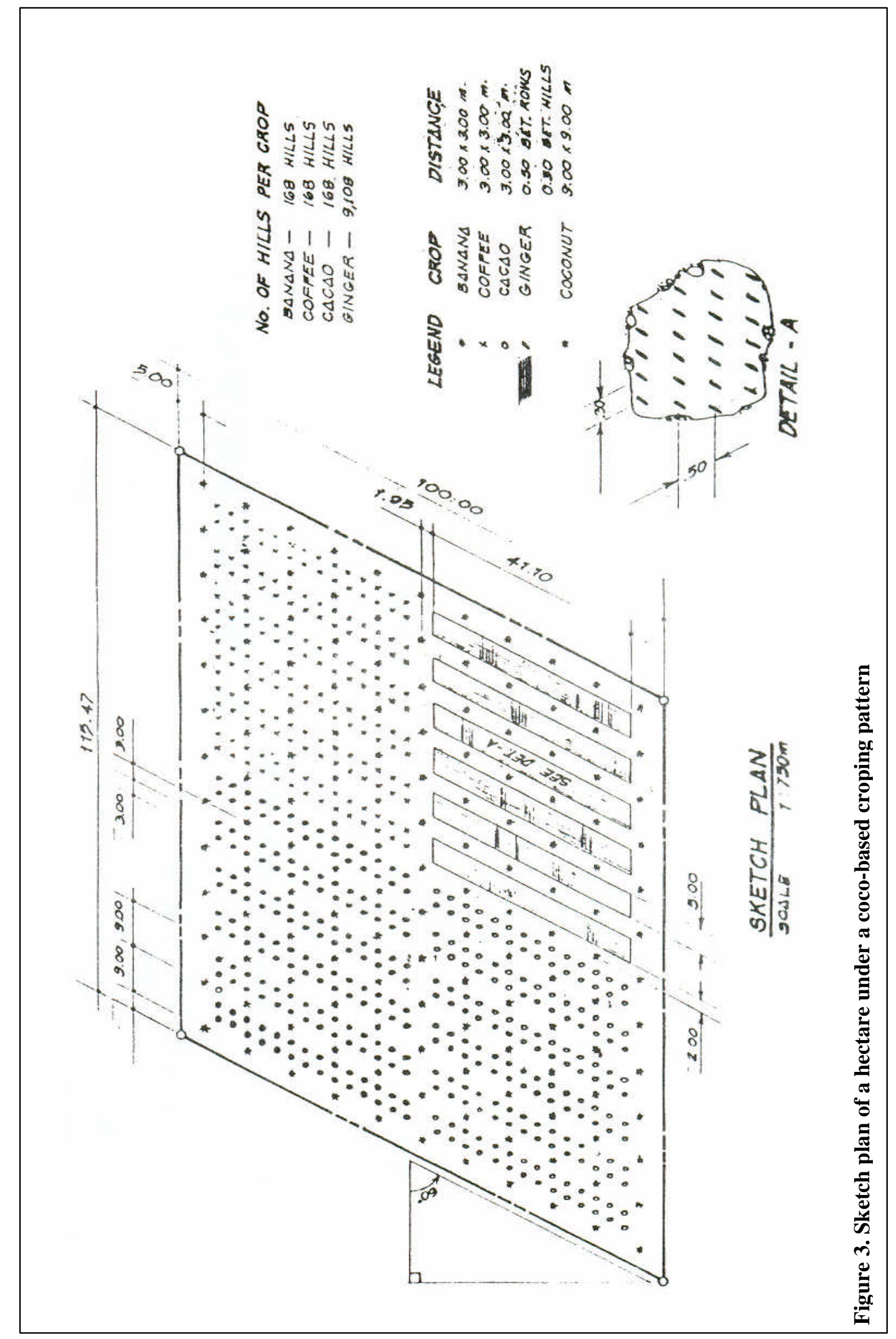




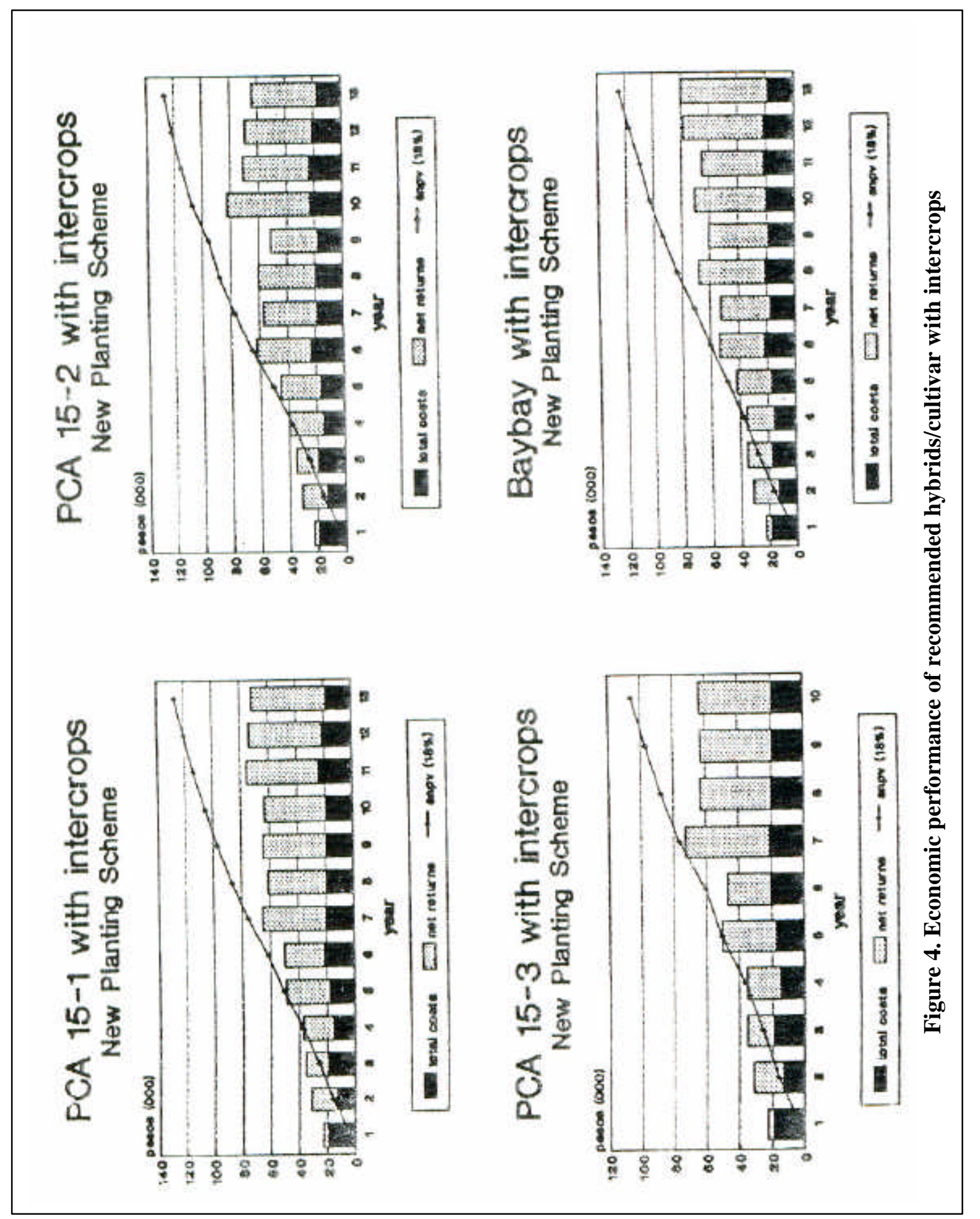


PCA $15-1$

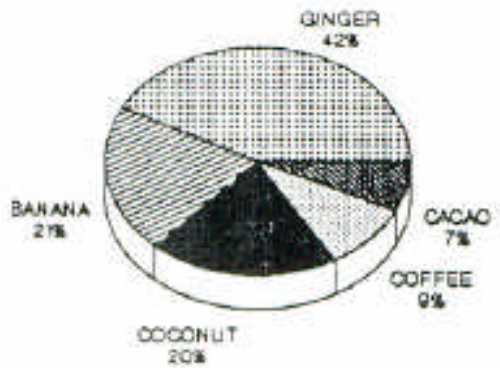

PCA 15-3

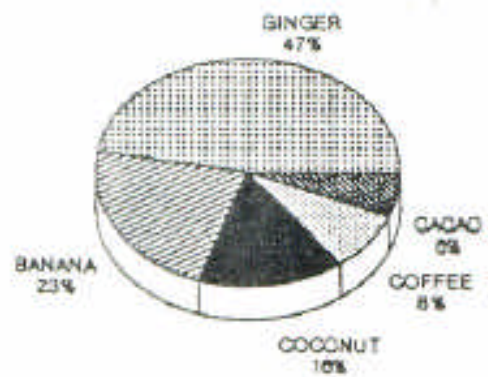

PCA 15-2

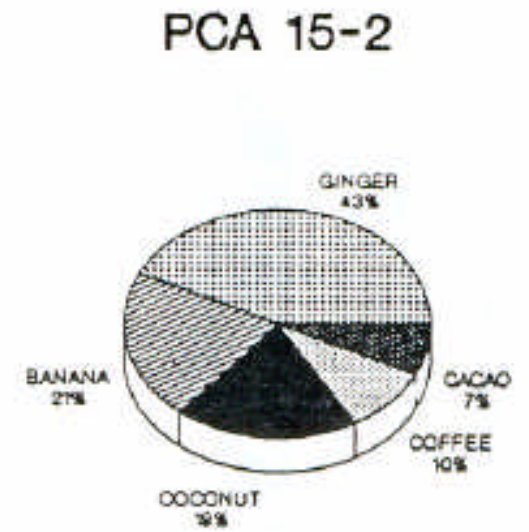

BAYBAY

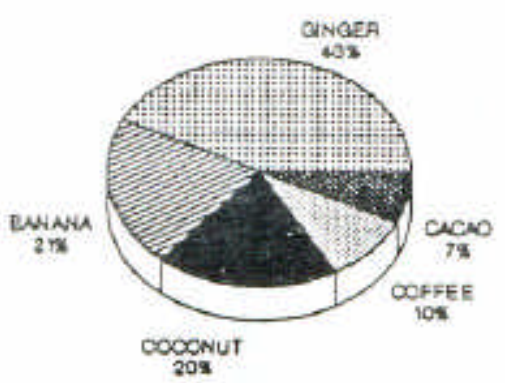

Figure 5. Contribution of each enterprice to gross income 